\title{
Sociodemographic and health characteristics of formal and informal caregivers of elderly people with Alzheimer's Disease
}

Características sociodemográficas e de saúde de cuidadores formais e informais de idosos com Doença de Alzheimer

Características sociodemográficas y de salud de cuidadores formales e informales de ancianos con enfermedad de Alzheimer

\author{
Gabriela Martins ${ }^{1}$ \\ Larissa Corrêa ${ }^{1}$ \\ Ana Julia de Souza Caparrol ${ }^{1}$ (1) \\ Paloma Toledo Afonso dos Santos ${ }^{1}$ \\ Leticia Maria Brugnera ${ }^{1}$ \\ Aline Cristina Martins Gratão ${ }^{1}$
}

1. Universidade Federal de São Carlos. São Carlos, SP, Brasil.

Corresponding author:

Gabriela Martins.

E-mail: gabrielamartinss93@gmail.com.

Submitted on $11 / 09 / 2018$

Accepted on 01/22/2019.

DOI: 10.1590/2177-9465-EAN-2018-0327

\begin{abstract}
Objective: to evaluate and compare the sociodemographic characteristics, depressive symptoms, anxiety and perceived stress of formal and informal caregivers of elderly people with Alzheimer's disease. Method: Quantitative, cross-sectional and comparative study with 44 caregivers that were divided into two groups of 26 informal caregivers (IC) and 18 formal caregivers (FC). The Instrument for Characterization of the Caregiver, Beck Depression Inventory (BDI), Beck Anxiety Inventory (BAI) and Perceived Stress Scale (PSS) were applied. Results: Of those IC, the majority were women (96.2\%), mean age of 52.9 years, majority represented by sons (daughters) $(65.4 \%)$. They presented, on average, depressive symptoms (10.1\%), anxiety symptoms (11.5\%) and scored 32.1 in the PSS. The FC group, the majority were women (94.4\%), mean age of 45.2 years were not related to the elderly people (66.7\%). They presented, on average, depressive symptoms $(7.1 \%)$, anxiety symptoms $(6.4 \%)$ and scored 31.7 in the PSS. Conclusion: Similarities were shown in the sociodemographic aspects, but the groups differ in the health profile, revealing an alert for the planning of interventions looking for health promotion and disease prevention. Implications for practice: The study contributes to the improvement of the caregivers' quality of life.
\end{abstract}

Keywords: Alzheimer's disease; Caregivers; Depression; Anxiety.

\section{RESUMO}

Objetivo: avaliar e comparar as características sociodemográficas, sintomas depressivos, de ansiedade e estresse percebido em cuidadores formais e informais de idosos com Doença de Alzheimer. Método: Estudo quantitativo, transversal e comparativo, realizado com 44 cuidadores, divididos em dois grupos: 26 cuidadores informais (Cl) e 18 cuidadores formais (CF). Aplicou-se o Instrumento para Caracterização do Cuidador, Inventário de Depressão de Beck (BDI), Inventário de Ansiedade de Beck (BAI) e Escala de Estresse Percebido (PSS). Resultados: Dos Cl, a maioria eram mulheres (96,2\%), representada por filhos(as) (65,4\%), com idade média de 52,9 anos. Apresentaram, em média, sintomas depressivos $(10,1 \%)$, sintomas de ansiedade $(11,5 \%)$ e pontuaram 32,1, no PSS. Dos CF, a maioria eram mulheres (94,4\%), idade média de 45,2 anos, sem grau de parentesco com os idosos (66,7\%). Apresentaram, em média, sintomas depressivos (7,1\%), sintomas de ansiedade $(6,4 \%)$, e pontuaram 31,7, no PSS. Conclusão: Revelaram-se similaridades nos aspectos sociodemográficos, porém os grupos diferem-se no perfil de saúde, revelando um alerta no planejamento de intervenções visando à promoção de saúde e prevenção de doenças. Implicações para a prática: $O$ estudo contribui para melhorar a qualidade de vida dos cuidadores.

Palavras-chave: Doença de Alzheimer; Cuidadores; Depressão; Ansiedade.

\section{REsumen}

Objetivo: evaluar y comparar las características sociodemográficas, síntomas depresivos, ansiosos y estrés percibido de cuidadores formales e informales de ancianos portadores de la enfermedad de Alzheimer. Método: Estudio cuantitativo, transversal y comparativo, realizado con 44 cuidadores divididos en dos grupos de 26 cuidadores informales $(\mathrm{Cl})$ y 18 cuidadores formales (CF). Se aplicó el Instrumento para Caracterización del Cuidador, Inventario de Depresión de Beck (BDI), Inventario de Ansiedad de Beck (BAl) y Escala de estrés Percibido (PSS). Resultados: De los Cl, mayoría mujeres (96,2\%), edad media de 52,9 años, mayoría representada por hijos(as) $(65,4 \%)$. En promedio, los síntomas depresivos (10,1\%), síntomas de ansiedad $(11,5 \%)$ y puntualizó de 32,1 en el PSS. De los CF, mayoría mujeres (94,4\%), edad media de 45,2 años, no poseen grado de parentesco con los ancianos (66,7\%). En promedio, los síntomas depresivos (7,1\%), síntomas de ansiedad $(6,4 \%)$ y puntuaron un escore de 31,7 en el PSS. Conclusión: Se revelan similitudes en los aspectos sociodemográficos, pero los grupos difieren en el perfil de salud, revelando una alerta para la planificación de intervenciones para promoción de salud y prevención de enfermedades. Implicaciones para la práctica: El estudio contribuye a la mejora de la calidad de vida de los cuidadores.

Palabras clave: Enfermedad de Alzheimer; Cuidadores; Depresión; Ansiedad. 


\section{INTRODUCTION}

The ageing of the population is a worldwide process, seen both in developing countries and in developed countries. ${ }^{1}$ In this sense, it is possible to notice transitions in the demographic structure, through a series of changes that affect the different spheres of an economic, political and social organization. ${ }^{2}$

On the other hand, the demographic transition has brought about successive changes in the epidemiological profile, given that the immediate consequence of this process was the decline of the incidence of infectious diseases, in addition to the rise in non-transmissible chronic diseases (NTCD), so that the most prevalent are the cardiovascular and neurodegenerative diseases. $^{3}$

Among the neurodegenerative diseases the dementia syndromes are included, with the, Alzheimer's Disease (AD) as the most frequent etiology ${ }^{4}$, characterized by neurological alteration which presents progressive, degenerative, slow and irreversible condition, and may be defined by the loss of the harmonious functioning of the cognitive and behavioral functions. ${ }^{4}$

As a consequence, the AD restricts the autonomy, the independence for daily life activities - feeding, bathing, dressing, moving, having urinary and fecal continence, taking medicines, among others -, as well as the quality of life of elderly people, leading to an increase in the demand of care and constant supervision. ${ }^{5}$

In this context, the valuing of the care taken by the caregivers emerges, who can be represented both by the formal caregivers, and by the informal caregivers. ${ }^{6}$ In this manner, the formal caregivers are professionals paid who work in homes or Long - Term Care Institutions (ILPIs), offering service with workload previously established. ${ }^{6}$ On the other hand the informal caregivers are represented by the family members, friends or neighbors, whose role is to provide the care in the domicile in a voluntary manner, without financing benefits and carrying out the activity full time. ${ }^{6}$

Due to the demand for the care taken to dependent elderly people, damage to health are reported by these professionals, due to the existence of stressor events regarding the act of caring, that causes negative influence in the quality of life of these people. ${ }^{7}$ This way, Borges (2017) noted that about $87.9 \%$ of the caregivers presented complications in their health, since after assuming the occupation, evidenced at least one disease. ${ }^{7}$

As a result of the progressive loss of memory and autonomy, concurrently with the behavioral and psychological changes of the sick elderly people, the caregivers are submitted to psychological disturbs, such as anxiety, depression and stress, when compared with individuals who do not play this function. ${ }^{7}$

In view of this, the formal caregiver tends to suffer negative consequences because of the care carried out, however the informal caregiver can present a higher level of these psychological disturbs, due to the overload caused by the following factors: degree of dependence in the basic and intermediate daily life activities; time spent for care; level of cognitive impairment of the elderly people assisted; and perception of changes in its family structure. ${ }^{8}$
Therefore, these caregivers need professional support and an environment to share insecurities and expectations, independently whether the care provided is formal or informal. The attention to the caregiver's health should be established from its capacity to determine this public's health needs, and to plan and assess the interventions related to the care for the people, based on their wishes and particularities.

In the light of the above, the objective of the present study was to assess and compare the socio-demographic and health profile of the formal and informal caregivers of elderly people with Alzheimer. For that purpose, we opted to assess, compare and identify the more important factors for depression, anxiety and stress perceived in these caregivers, and its relationship to the sex, age, time spent for care, education and degree of dependence of the elderly people care receiver.

\section{METHOD}

It's a quantitative, cross-sectional and comparative study, for verification of the level of stress, depressive symptoms and of anxiety in formal and informal caregivers of elderly people who are users of a private health care plan users in the municipality of São Carlos-SP.

The participants came from the Department of Home Healthcare (DHHC), belonging to a health operator (agreement), of private character. In total, there were 200 patients registered in the Home Healthcare and, approximately, $80 \%$ of this population were elderly people with Alzheimer disease diagnosis who had informal and formal caregivers for their daily care. The list of elderly people with the respective caregivers was provided by the coordinator of the Department of Home Healthcare of the Health Operator $(n=160)$.

As inclusion criteria, were considered informal caregivers of elderly people with Alzheimer disease diagnosis, who provided the care for more than one year, did not receive wage from the other family members to provide the care and were convened to the health operator. Furthermore, the formal caregivers, who were remunerated and took care of the elderly people with $A D$ for more than one year. As exclusion criteria, were caregivers with age less than 18 years, or that had some form of physical or mental disability that would make impossible the participation in the research.

The data collection was carried out in the first semester of 2017, being that, from the list of contacts provided by the coordinator of the $\mathrm{DHHC}$, the researcher called all with the aim of inviting them to participate in the research and, while respecting the inclusion criteria. The meeting was scheduled. On the date set, the caregivers signed the Free Informed Consent Form to participate in the research and were evaluated, in private sector, in the own health operator or in the own home. That way, they were divided into two groups of 18 formal caregivers and 26 informal caregivers.

The project was submitted and approved by the Research Ethics Committee with Human Beings of the Federal University of São Carlos, CAAE 65119517.1.0000.5504 (Opinion No. 
2.069.671/2017). For the evaluation, the following instruments were used:

The Instrument for characterization of the caregiver was created by the researchers, allowing to know it by means of the following particularities: sex, age, marital status, school degree, kinship, hours devoted to the care, types of diseases (dyslipidemia, diabetes, high blood pressure, heart disease, osteoporosis or others), type of care and support received.

The Beck Anxiety Inventory (BAl) was validated in Brazil by Cunha (2001), and evaluates common symptoms of anxiety from a list of 21 symptoms, with four alternatives for each one, in ascending order of the degree of anxiety. ${ }^{9-11}$ This instrument was validated for use in Brazil, and proposing the following classification: $0-10$ points, minimal; $11-19$, light; $20-30$, moderate; and $31-63$, severe. ${ }^{9-11}$ The anxiety is considered clinically important from the light degree..$^{9-11}$

The Beck Depression Inventory $(B D I)$ is a symptomatic of depression. ${ }^{10}$ It consisted of a questionnaire with 21 items, of multiple choice, with four alternatives, for each one and score ranging from zero to three points..$^{10}$ The sum of points provides a total score that indicates the intensity of the depression, ranging among the degrees: minimal, light, moderate and severe..$^{10}$ In Brazil, an extensive work was carried out to develop a Portuguese version of $\mathrm{BDI}$ and study of its psychometric properties, with authorization of The Psychological Corporation and support of the Home of the Psychologist. ${ }^{11}$ The classification of the intensity of depression, based on the BDI scores in Brazilian standards, is: minimal (0-11), light (12-19), moderate (20-35), severe (36-63). ${ }^{11}$

The Perceived Stress Scale (Perceived Stress Scale, PSS10) was developed by Cohen et al. (1983) and translated and validated for Brazil by Luft et al. (2007). ${ }^{12-13}$ The items were designed to verify how much the respondents evaluate their lives as unpredictable, uncontrollable and overloaded, and how much they perceive the situations as stressful. ${ }^{12-13}$ This is a general scale, that can be used in diverse age groups. ${ }^{12-13}$ The PSS has 14 questions with response options that range from zero (never) to four (always). ${ }^{(12-13)}$ Some questions have positive connotation and others, negative, adjusting the $\mathrm{m}$ the moment of the punctuation. ${ }^{12-13}$ The total of the scale is the sum of the punctuations of these 14 questions and the scores can vary between zero and 56 , in that, the higher the punctuation, the higher the level of the stress perceived by the individual. ${ }^{12-13}$

For the analysis of data, the descriptive statistics was used, being: the categorical variables described by percentage; the continuous variables represented by the central trend (mean); and the variability, by the standard deviation. The results of outcome variables (anxiety, depression and stress) were submitted to the assessment of normality by the Kolmogorov-Smirnov test and, after the normality confirmation, parametric tests were applied. The Pearson's chi-square test (X2) was used to compare the dichotomous categorical variables between the groups. The outcome variables means were compared (formal $\mathrm{x}$ informal caregivers) and analyzed by means of the Student $T$ test for independent samples. The Statistical Package for the Social Sciences software (SPSS) version 21.0 was used for the analysis of data, considering significant the $p$-value $\leq 0.05$.

In addition, multi-analyses were carried out to identify the factors associated with psychological variables, treated as the indication of depressive symptoms, high levels of stress and anxiety. The sociodemographic profile variables and information about the care context (independent variables) were tested in the association with the psychological variables (dependent variables). Through the Chi-Square test with Odds Ratio (OR) statistics and $95 \%$ confidence interval (Cl95\%), it is sought to analyze the associations between the above- mentioned dependent categorical variables and the independent. The associations and correlations considered statistically significant were those that obtained $p$-value $\leq 0.05$.

\section{RESULTS}

In Table 1, the sociodemographic characteristics of the 44 caregivers are observed, with 26 (59.1\%) informal (IC) and 18 $(40.9 \%)$ formal (FC). The sample had female predominance both in IC $(96.2 \%)$ group and of FC (94.4\%), and the mean age of the IC $(52.9 \%)$ was higher than FC $(45.2 \%)$. The level of education was shown from the quantity of years of study, that is, the $\mathrm{FC}(10.1$ $\%)$ have higher level than those of IC $(9.6 \%)$. As to the degree of kinship with the elderly people, the majority of the IC were sons (daughters) $(65.4 \%)$ or husbands (wives) (19.2\%). Still, the IC evidenced more time for care in daily hours than the FC; that is, 16.6 hours and 13.0 hours, respectively, pointing out that the IC have more time addressed to the care for the elderly people.

In Table 2, the health profile and the support that the caregivers receive by Religious Institutions, NGOs, Support Groups, Clubs or Social Assistance Service are observed. The total average of diseases was higher among the IC $(1.31 \%)$ than the FC $(0.7 \%)$. Regarding the health profile, the average of the IC who presented depressive symptoms, anxious and of perceived stress was higher than the FC; that is, IC $(10.1 \%)$ and FC $(7.1 \%)$, for depressive symptoms, IC (11.5\%) and FC (6.4\%) for anxiety and IC $(32.1 \%)$ and FC $(31.7 \%)$ for perceived stress.

In Table 3, the type of care provided to the elderly is noticed. The FC carried out the most part of the care - except for sleep/ rest -, being $72.2 \%$ and $73.1 \%$ among the IC, in addition to the monitoring related to the consultations; that is, $(61.1 \%)$ and $80.8 \%$ for the IC.

In Table 4, the association between the independent variables (sociodemographic profile and information about the care context) and dependent (depressive symptoms, of anxiety and stress) of the informal caregivers is identified. Thus, "Care for an elderly for 4 years or above" and "Have depressive symptoms" was the only association that showed as significant; that is, the fact of caring for an elderly for 4 years or more showed itself to be a protective factor for depressive symptoms. 
Table 1. Distribution of the caregivers according to sociodemographic aspects. São Carlos - SP, 2018

\begin{tabular}{|c|c|c|c|c|}
\hline Variables & Categories & $\begin{array}{c}\text { Informal Caregiver } \\
(n=26) n(\%)\end{array}$ & $\begin{array}{c}\text { Formal Caregiver } \\
(n=18) n(\%)\end{array}$ & $p$ Value \\
\hline \multirow[t]{9}{*}{ Age Group Mean (PD) } & & $52.9(1 ., 3)$ & $45.2(13.5)$ & \\
\hline & \multirow{2}{*}{$20-39$} & 4 & 6 & $0.104 * * *$ \\
\hline & & 15.4 & 33.3 & \\
\hline & \multirow{2}{*}{$40-59$} & 14 & 9 & \\
\hline & & 53.8 & 50.0 & \\
\hline & \multirow{2}{*}{$60-79$} & 6 & 3 & \\
\hline & & 23.1 & 16.7 & \\
\hline & \multirow{2}{*}{80 years or more } & 2 & 0 & \\
\hline & & 7.7 & 0.0 & \\
\hline \multirow[t]{4}{*}{ Sex } & \multirow{2}{*}{ Female } & 25 & 17 & $1.000 * * * *$ \\
\hline & & 96.2 & 94.4 & \\
\hline & \multirow{2}{*}{ Male } & 1 & 1 & \\
\hline & & 3.8 & 5.6 & \\
\hline Marital status & & & & $1.000^{* * * *}$ \\
\hline \multirow{4}{*}{ Have a partner? } & \multirow{2}{*}{ Yes } & 15 & 10 & \\
\hline & & 57.7 & 55.6 & \\
\hline & \multirow{2}{*}{ No } & 11 & 8 & \\
\hline & & 42.3 & 44.4 & \\
\hline \multirow[t]{9}{*}{ Education } & & $9.6(4.6)$ & $10.1(2.9)$ & $0.643 * * *$ \\
\hline & \multirow{2}{*}{ Illiterate } & 1 & 0 & \\
\hline & & 3.8 & 0.0 & \\
\hline & \multirow{2}{*}{1 to 4 years } & 5 & 1 & \\
\hline & & 19.2 & 5.6 & \\
\hline & \multirow{2}{*}{5 to 8 years } & 6 & 5 & \\
\hline & & 23.1 & 27.8 & \\
\hline & \multirow{2}{*}{9 years or above } & 14 & 12 & \\
\hline & & 53.8 & 66.7 & \\
\hline \multirow[t]{7}{*}{ Individual income } & & & & $0.333 * * * * *$ \\
\hline & \multirow{2}{*}{1 to $3 \mathrm{SM}^{*}$} & 15 & 17 & \\
\hline & & 57.7 & 94.4 & \\
\hline & \multirow{2}{*}{4 to $6 \mathrm{SM}^{*}$} & 6 & 1 & \\
\hline & & 23.1 & 5.6 & \\
\hline & \multirow{2}{*}{$7 \mathrm{SM}$ *or above } & 2 & 0 & \\
\hline & & 7.7 & 0.0 & \\
\hline \multirow[t]{3}{*}{$\begin{array}{l}\text { Kinship with the el- } \\
\text { derly }\end{array}$} & & & & $000^{* * *}$ \\
\hline & \multirow{2}{*}{ Husband(wife) } & 5 & 0 & \\
\hline & & 19.2 & 0.0 & \\
\hline
\end{tabular}




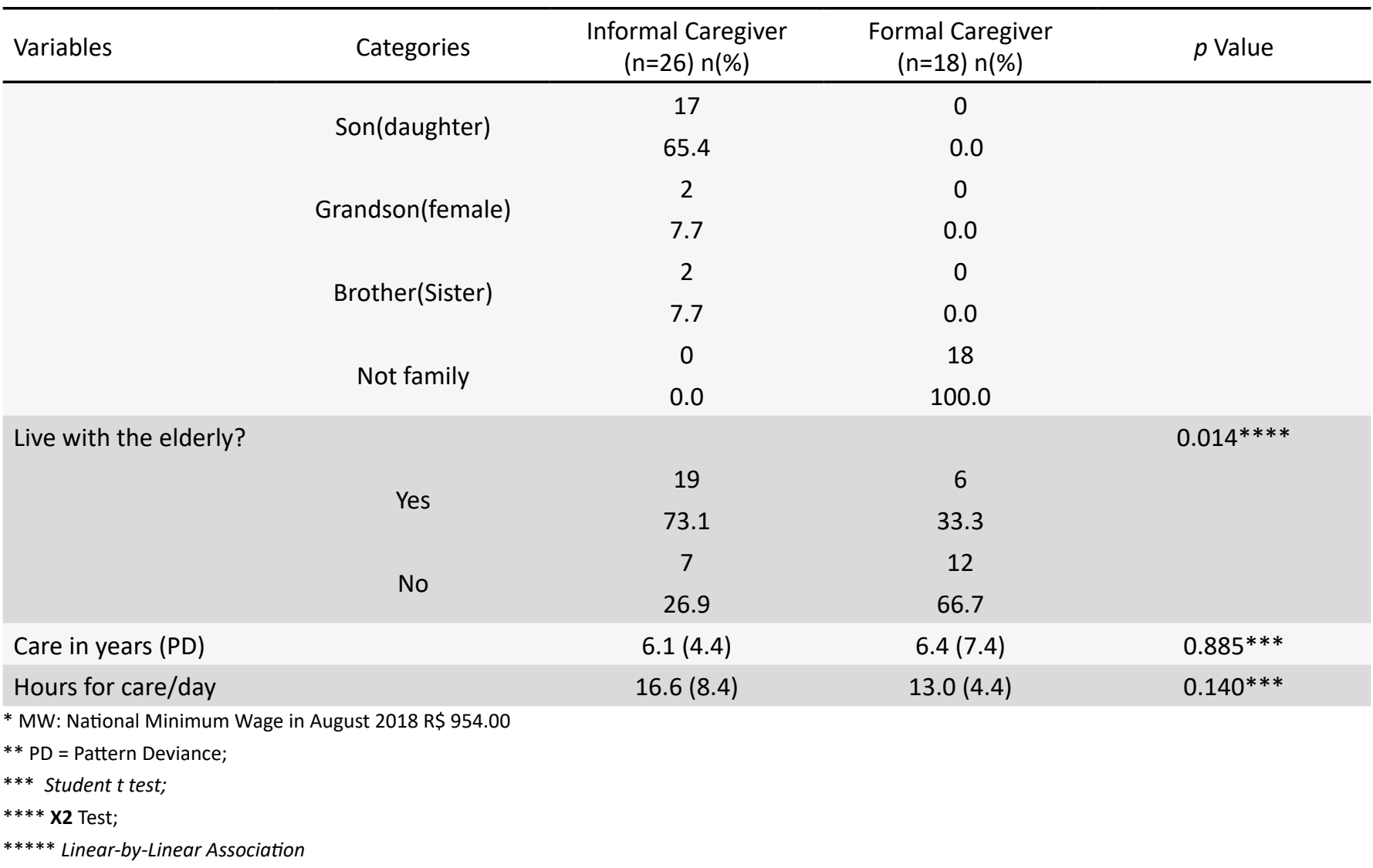

Table 2. Distribution of the caregivers according to the health profile. São Carlos - SP, 2018

\begin{tabular}{|c|c|c|c|c|}
\hline Variables & Categories & $\begin{array}{c}\text { Informal Caregiver } \\
\quad(n=26) n(\%)\end{array}$ & $\begin{array}{l}\text { Formal Caregiver } \\
\qquad(n=18) n(\%)\end{array}$ & $p$ Value \\
\hline \multirow[t]{11}{*}{ Total of diseases (DP) } & & $1.31(0.7)$ & $0.7(0.9)$ & $0.017^{* *}$ \\
\hline & \multirow{2}{*}{ None } & 1 & 10 & \\
\hline & & 3.8 & 55.6 & \\
\hline & \multirow{2}{*}{ One } & 19 & 5 & \\
\hline & & 73.1 & 27.8 & \\
\hline & \multirow{2}{*}{ Two } & 4 & 2 & \\
\hline & & 15.4 & 11.1 & \\
\hline & \multirow{2}{*}{ Three } & 1 & 1 & \\
\hline & & 3.8 & 5.6 & \\
\hline & \multirow{2}{*}{ Four } & 1 & 0 & \\
\hline & & 3.8 & 0.0 & \\
\hline \multirow[t]{7}{*}{ Receive support? (PD) } & & $0.4(0.5)$ & $0.2(0.5)$ & $0.416^{* *}$ \\
\hline & \multirow{2}{*}{ None } & 16 & 14 & \\
\hline & & 61.5 & 77.8 & \\
\hline & \multirow{2}{*}{ One } & 9 & 3 & \\
\hline & & 34.6 & 6.7 & \\
\hline & \multirow{2}{*}{ Two } & 1 & 1 & \\
\hline & & 3.8 & 5.6 & \\
\hline
\end{tabular}




\begin{tabular}{|c|c|c|c|c|}
\hline Variables & Categories & $\begin{array}{c}\text { Informal Caregiver } \\
(n=26) n(\%)\end{array}$ & $\begin{array}{l}\text { Formal Caregiver } \\
\qquad(n=18) n(\%)\end{array}$ & $p$ Value \\
\hline \multirow[t]{9}{*}{$\begin{array}{l}\text { Depressive } \\
\text { Symptoms(PD) }\end{array}$} & & 10.1 (9.7) & $7.1(6.1)$ & $0.221^{* *}$ \\
\hline & \multirow{2}{*}{ Minimal } & 19 & 16 & \\
\hline & & 72.8 & 89.1 & \\
\hline & \multirow{2}{*}{ Light } & 4 & 1 & \\
\hline & & 15.4 & 5.6 & \\
\hline & \multirow{2}{*}{ Moderate } & 2 & 1 & \\
\hline & & 7.6 & 5.6 & \\
\hline & \multirow{2}{*}{ Severe } & 1 & 0 & \\
\hline & & 3.8 & 0.0 & \\
\hline \multirow[t]{9}{*}{$\begin{array}{l}\text { Anxiety Symptoms } \\
\text { (PD) }\end{array}$} & & 11.5 (9.6) & $6.4(6.3)$ & $0.038^{* *}$ \\
\hline & \multirow{2}{*}{ Minimal } & 14 & 15 & \\
\hline & & 53.8 & 83.7 & \\
\hline & \multirow{2}{*}{ Light } & 9 & 2 & \\
\hline & & 34.5 & 11.2 & \\
\hline & \multirow{2}{*}{ Moderate } & 1 & 1 & \\
\hline & & 3.8 & 5.6 & \\
\hline & \multirow{2}{*}{ Severe } & 2 & 0 & \\
\hline & & 7.6 & 0.0 & \\
\hline Perceived Stress (PD) & & $32.1(5.7)$ & $31.7(5.2)$ & $0.832 * *$ \\
\hline
\end{tabular}

* PD = Pattern Deviance;

** Student $t$ test

Table 3. Distribution of the caregivers according to the type of care provided to the elderly. São Carlos - SP, 2018

\begin{tabular}{|c|c|c|c|c|}
\hline Variable & Category & $\begin{array}{c}\text { Informal Caregiver } \\
(n=26) n(\%)\end{array}$ & $\begin{array}{c}\text { Formal } \\
\text { Caregiver( }(n=18) n(\%)\end{array}$ & $p$ Vale \\
\hline \multirow{14}{*}{ Type of care } & \multirow{2}{*}{ Body Hygiene } & 16 & 16 & \multirow{2}{*}{0.046} \\
\hline & & 61.5 & 88.9 & \\
\hline & \multirow{2}{*}{ Oral Hygiene } & 14 & 15 & \multirow{2}{*}{0.042} \\
\hline & & 53.8 & 83.3 & \\
\hline & \multirow{2}{*}{ Elimination } & 13 & 12 & \multirow{2}{*}{0.359} \\
\hline & & 50.0 & 66.7 & \\
\hline & \multirow{2}{*}{ Feeding } & 21 & 18 & \multirow{2}{*}{0.051} \\
\hline & & 80.8 & 100.0 & \\
\hline & \multirow{2}{*}{ Control of medicines } & 21 & 17 & \multirow{2}{*}{0.690} \\
\hline & & 80.8 & 94.4 & \\
\hline & \multirow{2}{*}{ Sleep/Rest } & 19 & 13 & \multirow{2}{*}{1.000} \\
\hline & & 73.1 & 72.2 & \\
\hline & \multirow{2}{*}{$\begin{array}{l}\text { Monitoring in the Con- } \\
\text { sultations }\end{array}$} & 21 & 11 & \multirow{2}{*}{0.155} \\
\hline & & 80.8 & 61.1 & \\
\hline
\end{tabular}


Table 4. Association between variables "Beck Depression", "PSS" and "Beck Anxiety" in the informal caregivers $(\mathrm{n}=26)$. São Carlos, 2018

\begin{tabular}{|c|c|c|c|c|}
\hline \multirow[b]{2}{*}{ Independent Variables } & \multirow[b]{2}{*}{ Categories } & \multicolumn{3}{|c|}{ Dependent Variables } \\
\hline & & $\begin{array}{c}\text { Beck Depression }>11 \\
\text { Odds ratio }(95 \% \mathrm{IC})\end{array}$ & $\begin{array}{c}\text { PSS >32 Odds ratio } \\
(95 \% \mathrm{IC})\end{array}$ & $\begin{array}{c}\text { Beck Ansiety }>10 \text { Odds } \\
\text { ratio }(95 \% \mathrm{IC})\end{array}$ \\
\hline \multirow[t]{5}{*}{$\begin{array}{l}\text { Sociodemographic } \\
\text { profile }\end{array}$} & Age (>49 years) & $0.97(0.16-5.59)$ & $2.62(0.52-13.06)$ & $1.05(0.22-5.00)$ \\
\hline & $\begin{array}{l}\text { Marital Status (with } \\
\text { partner) }\end{array}$ & $5.41(0.80-36.35)$ & $1.37(0.28-6.53)$ & $3.50(0.6-17.88)$ \\
\hline & Education ( $<5$ years) & $0.46(0.04-4.89)$ & $1.00(0.16-6.20)$ & $0.16(0.01-1.66)$ \\
\hline & $\begin{array}{c}\text { Individual Income (<2 } \\
\text { MW) }\end{array}$ & $3.50(0.34-35.37)$ & $1.00(0.18-5.28)$ & $0.80(0.15-4.24)$ \\
\hline & $\begin{array}{l}\text { Family Income }(<2 \\
\text { MW) }\end{array}$ & $1.28(0.22-7.49)$ & $1.00(0.20-4.85)$ & $1.28(0.26-6.27)$ \\
\hline \multirow[t]{4}{*}{ Care context } & Kinship (sons) & $1.23(0.10-14.42)$ & $0.28(0.02-3.06)$ & $1.33(0.17-10.12)$ \\
\hline & $\begin{array}{c}\text { Cohabitation with the } \\
\text { elderly }\end{array}$ & $2.76(0.27-28.39)$ & $3.43(0.52-22.43)$ & $8.25(0.82-82.66)$ \\
\hline & $\begin{array}{c}\text { Time spent for care }(>4 \\
\text { years) }\end{array}$ & $0.97(0.01-0.98)$ & $2.56(0.52-12.43)$ & $0.27(0.05-1.40)$ \\
\hline & Daily care (>12 hours) & $1.20(0.20-6.88)$ & $1.86(0.39-8.89)$ & $2.66(0.53-13.21)$ \\
\hline
\end{tabular}

\section{DISCUSSION}

The results showed that there was female predominance in the caregivers of elderly people with AD (96.2\%). According to the literature, the responsibility attributed to the woman in the care context refers to the tendency of the persons of this sex to have longer life expectancy than the men, or, even, because they are younger than their partners. ${ }^{14}$

In the current study, the most caregivers were included in the age group from 40 to 59 years, both informal, and formal - $53.8 \%$ and $50.0 \%$, respectively. These data are similar to described in the study of Diniz et al. (2018), in that the predominant age of the formal and informal caregivers range between 36 and 56 years. ${ }^{15}$ This result can be related to the fact that the young adults have more vitality to carry out the care. ${ }^{16}$

As to the marital status, the most caregivers of elderly people had a companion, that is, $57.7 \%$ for the informal and $55.6 \%$ for the formal. This matches with the study of Orlandi et al. (2017), who evidenced that the most informal caregivers were married, once, due to factors as the woman's participation in the job marked, as well as the restructuring of the family's arrangements, there is the unavailability of persons to care for the elderly. ${ }^{17}$ This way, the partners are presented as the only option to perform this role. ${ }^{17}$ In addition, the study of Almeida et al. (2018) refers that the married women are more prone to develop care activities than the divorced, widows and singles. ${ }^{18}$

On the schooling question, the majority of the caregivers of elderly with AD had 9 years of schooling or above, being the informal $53.8 \%$ and the formal $66.7 \%$. This result is in accordance with findings of the research of Leite et al. (2017), whereby great part of the informal caregivers had more than 10 years of schooling. ${ }^{19}$ Furthermore, such level of schooling was also presented in the study of Diniz et al. (2018). ${ }^{15}$ This is a fundamental factor in the care for the elderly people, since the low schooling may influence directly in the quality of the service provided..$^{20}$

Regarding the individual income, the most caregivers received about 1 to 3 minimum wages, totaling $57.7 \%$ for the informal and $94.4 \%$ for the formal. The data corroborate with the study of Queiroz et al. (2018), which points out that the most caregivers have income equivalent to the same category. ${ }^{21} \mathrm{By}$ the other hand, in the study of Almeida et al. (2018), the caregivers of elderly people presented absence of income $(30.4 \%)$, receipt of one minimum wage $(34.8 \%)$ or income originated from other sources $(63 \%) .{ }^{18}$ The factor income of family caregivers may produce stressful situations, since, many times, these caregivers account for their income added to that of the elderly, in order to enable the expenditure administration ${ }^{16}$

Regarding to the degree of kinship, $65.4 \%$ of the informal caregivers were sons (daughters), $19.2 \%$ were husbands (wives), $7.7 \%$ were grandsons (granddaughters) and $7.7 \%$ were brothers (sisters). According to Queiroz et al. (2018), the fact that most of these caregivers were sons/husbands, strengthen the idea of the feeling of obligation of care for these relatives or, even, for lack of resources. ${ }^{21}$ Moreover, the authors expose some factors that influence the choice of the caregiver, such as proximity, coexistence, living with the elderly, free time and financial situation. ${ }^{21}$ However, regarding the formal caregivers, all of them reported that they did not have any kinship with the care receiver, that is, $100,0 \%$. 
A great part of the informal caregivers reported residing with the elderly who received the care, that is, $73.1 \%$. According to Queiroz et al. (2018), the cohabitation with the elderly causes a greater working day, making that the tasks performed become more frequent, and, consequently, can lead to an increased overload to the caregiver. ${ }^{21}$ For such, the support to the main caregivers is essential, to enable the division of tasks of the care carried out. ${ }^{17}$ In addition, it is needed the support of this population by means of the public equipments. ${ }^{22}$ Among the formal caregivers, $66.7 \%$ reported that they did not reside with the elderly.

In the study population, the time spent for care, in years, was expressed by the means 6.1 and 6.4 years, respectively, for the informal and formal caregivers. In addition, the hours of care, a day, constituted 16.6 hours worked by the group of the informal and 13.0 by the formal. According to Leite et al. (2017), there is the possibility that the caregivers does not receive the support necessary, such as the reduction of the workload, division of tasks and the access to the health public services, in an early way, according to the time required for the care. This, besides bringing consequences regarding the care for the elderly, could give rise to adverse health outcomes of this public. ${ }^{19}$

About the health profile, a significant difference in the number of diseases among the groups is observed, with informal caregivers presenting a higher average. Only the informal caregivers reported having a disease $(73.1 \%)$; what diverges from the study of Diniz et al. (2018), which evidenced the predominance of health complaints in the formal caregivers, such as back ache, what could be explained by the difference in the activities of care performed or work load. ${ }^{15}$ In addition, a practice suggested to try reducing the impacts generated is resumed in the adequacy of the caregivers' work day, before its individual context. ${ }^{15}$

In addition, the current study enabled us to know the psychiatric aspects of these caregivers, by means of depressive symptoms, anxious and of stress. Thus, the depressive symptoms average of the informal caregivers was higher than that found in the formal caregivers. In accordance with the study of Rossi et al. (2015), the depression is one of the most recurrent symptoms among the informal caregivers and can persist for up to four years after the elderly's death. ${ }^{16}$ In accordance with the literature, the caregivers with $A D$ tend to present higher indexes of depression, contributing both to adverse outcomes to the caregiver and to the early institutionalization of the care receiver. ${ }^{23}$

Regarding the anxious symptoms, it is noticed a significant distinction among the groups, given that the average of informal caregivers was also higher than among the formal caregivers. These results agree with the study of Rossi et al. (2015), in which the anxiety was one of the most frequent consequences after assuming the function of family member caregivers. ${ }^{16}$

In accordance with Rossi et al. (2015), taking responsible for the care of a dependent elderly - mainly for AD - consists in an impacting experience in the caregiver's life. ${ }^{16}$ Even more when attached to the care by a family member, since the caring for emerges many times in an unpredictable way, and the task needs to be constantly performed, being able to cause modifications in the caregivers' biopsychosocial health. ${ }^{16}$

As to the stress perceived, both the informal caregivers and the formal did not demonstrate significant levels of stress; however, the informal caregivers evidenced higher average in this symptom. Considering the national scenario, similar data were presented in a study conducted in the interior of São Paulo State, Brazil, since the caregivers punctuated in this scale an average of $19.9 \% .{ }^{24}$ Beyond this, in the study of Silva et al. (2018) the stress was reported by the most informal caregivers among the more prevalent symptoms..$^{20}$ According to the type and frequency of the activities used by the caregiver, there is the possibility of the establishment of stressful events, bringing adverse consequences in the life of this individual, such as the worsening of his quality of life. ${ }^{20}$

Therefore, it should be emphasized that, according to the risk when compared to the analysis of the depressive symptoms, anxious and of stress perceived, the informal caregivers presented higher levels of these psychological aspects compared with the formal caregivers. Factors such as feeling of overload resulting from the workload spent in the care for the elderly, complexity of care and, for commonly disregarding their own needs, generate an increase in the probability of these individuals manifest depressive and anxious symptoms. ${ }^{15}$

With regard to the type of care exerted for the elderly, the informal caregivers reported performing, more regularly, aid in the feeding, medicines control and monitoring in the consultations. By the other hand, the formal caregivers reported carrying out the activities of feeding, medicines control, body hygiene and oral hygiene. The repercussion of the disease of the elderly care receiver implies consequences - both for the elderly affected, and for the caregiver responsible - since the cognitive and behavioral functions impairment cause influence in the daily activities (DAs); such as, to maintain the body hygiene, to get dressed, to move, to have preserved urinary and fecal continence, to feed, to medicate itself, to put the house in order, among others. ${ }^{6}$

In the current study, the fact that the function of caregiver of elderly with $A D$ was performed for four years or above was shown as a protective factor for depressive symptoms. According to the study of Scalco et al. (2013), after the impact generated by the responsibility in the care for an elderly with dependence, beyond the implications caused by exerting this function, the informal caregivers initiate the search for the acceptance of the elderly condition, as well as the adaptation in the face of his current situation. ${ }^{25}$ In this direction, there are studies that relate this behavior to a greater resilience; that is, the development of positive attitudes, in order to help supporting an array of negative and harmful factors to health originated from the care process over the years, is strongly associated with lower rates of depression, better physical health and social support. ${ }^{26}$ Others 
authors argue that because the caregivers exert this function for a considerable period of time, positive feelings are awakened about the relationship caregiver-elderly. ${ }^{27}$

Therefore, the research contributions meet the importance of studying the differences and similarities between formal and informal caregivers, and of indicating them for their participation along with a social support net, in companionship groups, once enable the change of information about the elderly's disease, maximizing care already performed, in addition to change of experiences about feelings and expectancies of this public before the task of caring for. ${ }^{28}$ Moreover, there is need for the creation and implementation of health public policies addressed to the assistance of these individuals and the creation of a care plan, in order to point out ways of reduction of the generate impact, as well as to provide the increase of the support network to caregivers of dependent elderly people. ${ }^{29}$

In view of this, it is needed to direct our view towards the caregiver, who is frequently affected by psychiatric disturbances such as depression, anxiety and stress, arising from the task of caring for. For this, it is needed to guide the caregiver by addressing their expectations and goals, adapting them to the situation and, in addition, driving them to means of support available.

This study presents some limitations. As this is a study with caregivers of elderly people with Alzheimer, there was difficulty to carry out the collection - both along with the formal caregivers and the informal - once the type of care provided by them required, many times, integral period, making it difficult the availability of time, by reflecting in the small size of the sample. In addition, the cross section did not allow to establish a causality among the variables, making the analysis of results difficult.

\section{CONCLUSION}

The study evaluated and compared the sociodemographic and health profile in formal and informal caregivers with Alzheimer Disease. The significant differences were those represented by the relation of kinship with the elderly, the cohabitation with the elderly, anxiety symptoms, the care provided to the elderly - body hygiene activities, oral hygiene and feeding -, revealing values more evident to the informal relative caregiver familiar when compared with the formal non-relative caregiver.

In addition to, the fact that the elderly has been cared for 4 years or above, it has proven to be revealed to be a protective factor for depressive symptoms, both for the formal caregiver and the informal. In addition, it has contributed to the discussion about the planning of interventions such as support groups, implementation of public policies and development of care plans, in order to establish the assistance of the caregivers in the assistance scope, aiming at health promotion and prevention of diseases of these individuals.

Therefore, it is considered essential the support addressed not only towards the elderly that receive the care, as well as the caregiver, through actions that enable comprising their individual needs. Such practice should represent a support mechanism to this population, to ensure not only the reduction of depressive symptoms, of anxiety and stress perceived in the caregivers, as well as to improve the quality of care provided to the elderly with Alzheimer Disease.

Due to the findings of this study, influenced by the limiting factors cited, it is suggested the carrying out of future researches, given the relevance of understanding and analysis of the sociodemographic profile, in addition to the depressive symptoms, of anxiety and stress perceived in caregivers of the elderly with AD, as well as the scarcity regarding these themes is emphasized.

\section{FINANCING}

The study received financing support from the Brazilian National Council for Scientific and Technological Development (CNPQ) 2018-2019, Call number 001/2018 (129164/2018-6), for the Scientific Initiation (IC) mode, São Carlos, State of São Paulo - Brazil.

\section{REFERENCES}

1. Valentini IV, Zimmermann N, Fonseca RP. Ocorrência de depressão e ansiedade em cuidadores primários de indivíduos com demência tipo Alzheimer: estudos de casos. Est Interdisc Envelhec [Internet]. 2010 [cited 2017 Sep]; 15(2):197-217. Available from: http://seer.ufrgs.br/ RevEnvelhecer/article/view/15150/11480

2. Saad PM. O envelhecimento populacional e seus reflexos na área da saúde. Anais do VII Encontro Nacional de Estudos Populacionais [Internet]. 2016; [cited 2017 Sep]; p. 353-69. Available from: http://www. abep.org.br/publicacoes/index.php/anais/article/view/554/534

3. Silva JVF, Silva EC, Rodrigues ARA, Miyazawa AP. A relação entre o envelhecimento populacional e as doenças crônicas não transmissíveis: sério desafio de saúde pública. Ciênc Biol Saúde [Internet]. 2015 May [cited 2017 Sep];2(3):91-100. Available from: https://periodicos.set.edu. br/index.php/fitsbiosaude/article/view/2079

4. Goyanna NF, Freitas CASL, Brito MMC, Netto JJM, Gomes DF. Idosos com doença de Alzheimer: como vivem e percebem a atenção na estratégia saúde da família. Rev Fund Care Online [Internet]. 2017 Apr/ Jun; [cited 2017 Sep]; 9(2):379-86. Available from: http://www.seer. unirio.br/index.php/cuidadofundamental/article/view/5037/pdf_1. DOI: 10.9789/2175-5361.2017.v9i2.379-386

5. Ferreira APM, Castro AKP, Lima EA, Marques IA, Oliveira KMS, Macie RS, et al.. Doença de Alzheimer. Mostra Interdisciplinar do curso de Enfermagem [Internet]. 2016; [cited 2017 Sep]; 2(2). Available from http://publicacoesacademicas.unicatolicaquixada.edu.br/index.php/ mice/article/view/1151

6. Terra NL. Doença de Alzheimer. In: Terra NL, Moriguchi Y, Crippa A Nascimento N. Cuidando do seu idoso. Porto Alegre: EDIPUCRS;2015, p. 17-26. Available from: https://books.google.com.br/books?hl=pt-BR $\& \mid r=\& i d=a 2 h q D g A A Q B A J \& o i=f n d \& p g=P T 13 \& d q=d o e n \% C 3 \% A 7 a+d$ e+alzheimer\&ots=2nkOPF9XUA\&sig=QXa6S6RXWVDeAjfE4cmBZ1 $c N B t o \# v=$ onepage $\& q=$ doen $\% C 3 \% A 7 a \% 20$ de $\% 20$ alzheimer\& $f=$ false

7. Borges CJ. Estratégias de atenção aos cuidadores informais de idosos: pesquisa participante baseada na comunidade [Thesis]. Goiânia: Universidade Federal de Goiás/Faculdade de Enfermagem; 2017. Available from: https://repositorio.bc.ufg.br/tede/bitstream/tede/7325/5/ Tese\%20-\%20Cristiane\%20Jos\%C3\%A9\%20Borges\%20-\%202017. pdf

8. Brigola AG, Luchesi MB, Rossetti ES, Mioshi E, Inouye K, Pavarin SCl. Perfil de saúde de cuidadores familiares de idosos e sua relação com variáveis do cuidado: um estudo no contexto rural. Rev Bras Geriatr Gerontol [Internet]. 2017 May/Jun; [cited 2017 Sep]; 20(3):40920. Available from: http://www.scielo.br/scielo.php?pid=S180998232017000300409\&script=sci_arttext\&tlng=pt 
9. Beck AT, Epstein N, Brown G, Steer RA. An inventory for measuring clinical anxiety: psychometric properties. J Consult Clin Psychol [Internet]. 1988 Dec; [cited 2017 Sep]; 56(6):893-7. Available from: http://psycnet.apa.org/record/1989-10559-001. DOI: http://dx.doi. org/10.1037/0022-006X.56.6.893

10. Beck AT, Ward CH, Mendelson M, Mock J, Erbaugh J. An inventory for measuring depression. Arch Gen Psychiatry [Internet]. 1961 Jun;4:56171. Available from: https://www.ncbi.nlm.nih.gov/pubmed/13688369. DOI: 10.1001/archpsyc.1961.01710120031004

11. Cunha JA. Manual da versão em português das escalas de Beck. São Paulo: Casa do Psicólogo; 2001.

12. Cohen S, Kamarck T, Mermelstein R. A global measure of perceived stress. J Health Soc Behav [Internet] 1983 Dec; [cited 2017 Sep]; 24(4):385-96. Available from: https://www.jstor.org/stable/2136404. DOI: $10.2307 / 2136404$

13. Luft CDB, Sanches SO, Mazo GZ, Andrade A. Versão brasileira da Escala de Estresse Percebido: tradução e validação para idosos. Rev Saúde Pública [Internet]. 2007 Aug; [cited 2017 Oct]; 41(4):60615. Available from: http://www.scielo.br/scielo.php?script=sci_ar ttext\&pid=S0034-89102007000400015. DOI: $10.1590 /$ S003489102007000400015

14. Cesário VAC, Leal MCC, Marques APO, Claudino KA. Estresse e qualidade de vida do cuidador familiar de idoso portador de Doença de Alzheimer. Saúde Debate [Internet]. 2017; [cited 2017 Oct]; 41(112):171-82. Available from: http://www.scielo.br/scielo. php?pid=S0103-11042017000100171\&script=sci_abstract\&tlng=pt

15. Diniz MAA, Melo BRS, Neri CH, Casemiro FG, Figueiredo LC, Gaioli CCLO, et al. Estudo comparativo entre cuidadores formais e informais de idosos. Ciênc Saúde Coletiva [Internet]. 2018; [cited 2018 Sep 28]; 23(11):3789-98. Available from: http://www.scielo.br/pdf/csc/ v23n11/1413-8123-csc-23-11-3789.pdf

16. Rossi VEC, Soares MA, Vilela MBT, Alves A, Oliveira MG. Perfil dos cuidadores de idosos com Doença de Alzheimer de uma cidade do interior de Minas Gerais. Ciênc Et Praxis [Internet]. 2015; [cited 2018 Sep]; 8(16):27-32. Available from: http://revista.uemg.br/index.php/ praxys/article/view/2220/1203 ISSN 1983-912X

17. Santos-Orlandi AD, Brito TRP, Ottaviani AC, Rossetti ES, Zazzetta MS, Gratão ACM, et al. Perfil de idosos que cuidam de outros idosos em contexto de alta vulnerabilidade social. Esc Anna Nery [Internet] 2017 Jan; [cited 2018 Sep 28]; 21(1):e20170013. Available from: http://www.scielo.br/scielo.php?script=sci_arttext\&pid=S1414$81452017000100213 \&$ Ing=pt\&nrm=iso. DOI: http://dx.doi. org/10.5935/1414-8145.20170013

18. Almeida LPB, Meneses TMO, Freitas AVS, Pedreira LC. Características sociais e demográficas de idosos cuidadores e motivos para cuidar da pessoa idosa em domicílio. Rev Min Enferm [Internet]. 2018; [cited 2018 Sep]; 22:e-1074. Available from: http://www.reme.org. br/artigo/detalhes/1212. DOI: http://www.dx.doi.org/10.5935/14152762.20180004

19. Leite BS, Camacho ACLF, Jacoud MVL, Santos MSAB, Assis CRC, Joaquim FL. Relação do perfil epidemiológico dos cuidadores de idosos com demência e sobrecarga do cuidado. Cogitare Enferm [Internet]. 2017; [cited 2018 Sep]; 4(22):e50171. Available from: http://www.saude.ufpr.br/portal/revistacogitare/wp-content/ uploads/sites/28/2017/10/50171-219643-1-PB.pdf. DOI: 10.5380/ ce.v22i4.50171
20. Silva ILC, Lima GS, Storti LB, Aniceto P, Formighieri PF, Marques S. Sintomas neuropsiquiátricos de idosos com demência: repercussões para o cuidador familiar. Texto Contexto Enferm [Internet]. 2018 Aug; [cited 2018 Sep]; 27(3):e3530017. Available from: http://www.scielo. $\mathrm{br} /$ scielo.php?script=sci_arttext\&pid=S0104-07072018000300328\&ln $\mathrm{g}=$ en\&nrm=iso\&tlng=pt. DOI: 10.1590/0104-07072018003530017

21. Queiroz RS, Camacho ACLF, Gurgel JL, Assis CRC, Santos MLSC Perfil sociodemográfico e qualidade de vida de cuidadores idosos com demência. Rev Bras Geriatr Gerontol [Internet]. 2018 Apr/Mar; [cited 2018 Sep]; 21(2):205-14. Available from: http://www.scielo.br/scielo. php?pid=S1809-98232018000200205\&script=sci_arttext\&tlng=pt. DOI: 10.1590/1981-22562018021.170170

22. Jesus ITM, Orlandi AAS, Zazzetta MS. Sobrecarga, perfil e cuidado: cuidadores de idosos em vulnerabilidade social. Rev Bras Geriatr Gerontol [Internet]. 2018 Apr/Mar; [cited 2018 Sep]; 21(2):194204. Available from: http://www.scielo.br/scielo.php?script=sci arttext\&pid=S1809-98232018000200194\&lng=pt\&nrm=iso\&tlng=pt. DOI: 10.1590/1981-22562018021.170155

23. Guimarães LFO, Pinto CT, Tebaldi JB. Alzheimer: diagnóstico precoce auxiliando na qualidade de vida do cuidador. Memorialidades [Internet] $2015 \mathrm{Jul} / \mathrm{Dec}$; [cited $2018 \mathrm{Sep}$ ]; 12(23):11-30. Available from: http:// periodicos.uesc.br/index.php/memorialidades/article/view/1304/1102

24. Luchesi BM. Idosos cuidadores de idosos: atitudes em relação à velhice, sobrecarga, estresse e sintomas depressivos [Thesis] Ribeirão Preto (SP): Escola de Enfermagem de Ribeirão Preto/ Universidade de São Paulo; 2015. Available from: http://www.teses. usp.br/teses/disponiveis/22/22132/tde-28012016-154641/pt-br.php. DOI: 10.11606/T.22.2016.tde-28012016-154641

25. Scalco JC, Tavares KO, Vieira L, Silva JR, Bastos CCCB. O dia a dia de cuidadores familiares de idosos dependentes. Rev Kairós Gerontol [Internet]. 2013; [cited 2018 Sep]; 16(2):191-208. Available from: https:// revistas.pucsp.br/index.php/kairos/article/view/19072/14233 ISSN 2176-901X

26. Manzini CSS, Brigola AG, Pavarini SCI, Vale FAC. Fatores associados à resiliência de cuidador familiar de pessoa com demência: revisão sistemática. Rev Bras Geriatr Gerontol [Internet]. 2016; [cited 2018 Oct]; 19(4):703-14. Available from: http://www.scielo.br/pdf/rbgg/v19n4/ pt_1809-9823-rbgg-19-04-00703.pdf

27. Pocinho R, Belo P, Melo C, Navarro-Pardo E, Muñoz JJF. Relação entre o estado psicossocial do cuidador informal e o tempo de cuidado dos idosos da região centro de Portugal. Educ Humanismo [Internet]. 2017; [cited 2018 Sep]; 19(32):88-101. Available from: http:// revistas.unisimon.edu.co/index.php/educacion/article/view/2533. DOI: 10.17081/eduhum.19.32.2533

28. Cardoso VB, Almeida JL, Costa CD, Tebaldi JB, Mattos FA. A doença de Alzheimer em idosos e as consequências para cuidadores domiciliares. Memorialidades [Internet]. $2015 \mathrm{Jul} / \mathrm{Dec}$; [cited $2017 \mathrm{Sep}$ 28]; 12(24):113-49. Available from: http://periodicos.uesc.br/index.php/ memorialidades/article/view/1310

29. Fuhrmann AC, Bierhals CCBK, Santos NO, Paskulin LMG. Associação entre capacidade funcional de idosos dependentes e a sobrecarga do cuidador familiar. Rev Gaúcha Enferm [Internet]. 2015 Mar; [cited 2018 Sep]; 36(1):14-20. Available from: https://lume.ufrgs.br/bitstream/ handle/10183/117452/000966208.pdf?sequence=1\&isAllowed=y. DOI: 10.1590/1983-1447.2015.01.49163 